\title{
الطر:قة السمعية والشفهية في تعليم اللغة العربية
}

\section{Nur Istaqam dan Dhafrina Safrah}

(gmail: nistaqam@gmail.com)

\section{(Dosen Fakultas Tarbiyah IAI Muhammadiyah Bima)}

اللغة العربية هي إحدى من المواد اللغة الأجنبية التي يعلم في المدرسة والجامعة. إحدى من المهارات اللغوية التي يجب إتقانها الطلاب هي القدرة على الكلام أو القدرة على تلى تكوين

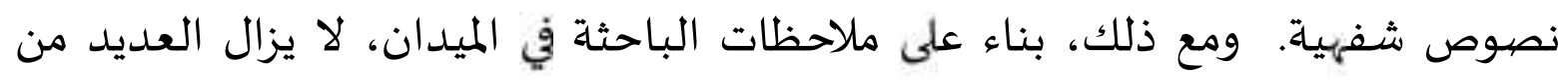

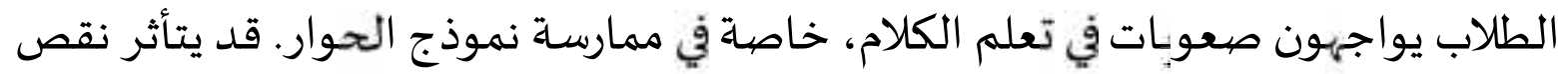
قدرة الطلاب على ممارسة نموذج الحوار بعدة العوامل، منها طربقة التعليم غير المناسبة

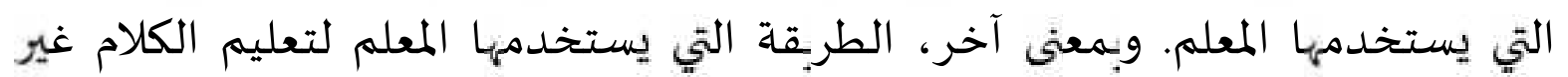

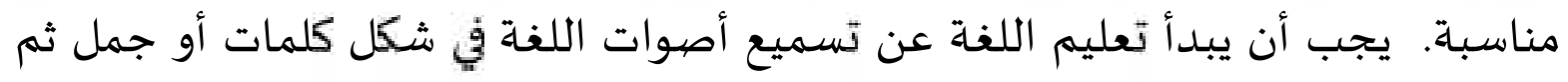

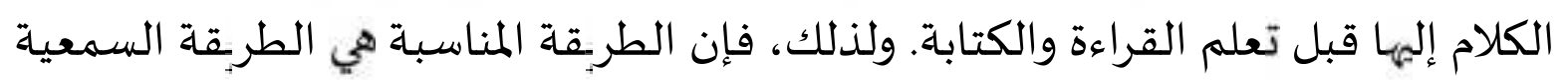

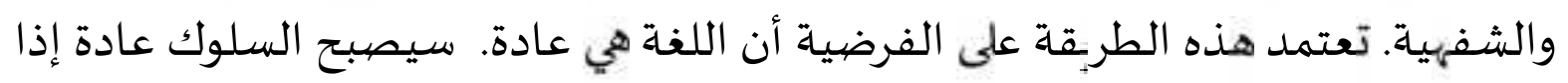

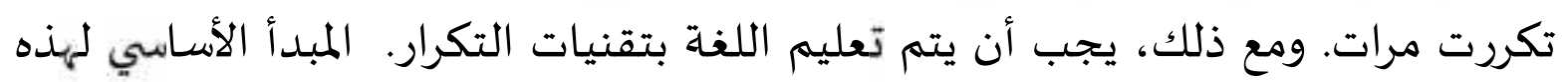
الطربقة هو تعليم اللغة، وليس تعليم عن قواعد اللغة. ولذلك يجب درب أن تملأ تعلم اللغة بأنشطة لغوباة وليست بأنشطة لتعلم قواعد اللغة. كلمات المفتاح: الطربقة السمعية والشفهية، تعليم اللغة العربية بلية

Bahasa Arab merupakan salah satu mata pelajaran bahasa asing yang diajarkan di sekolah maupun di perguruan tinggi. Salah satu keterampilan berbahasa yang harus dikuasai oleh siswa adalah kemampuan berbicara atau kemampuan menyusun teks lisan. Namun demikian, berdasarkan pengamatan peneliti di lapangan, banyak siswa yang masih mengalami kesulitan dalam belajar berbicara, khususnya dalam mempraktikkan model dialog. Kurangnya kemampuan siswa dalam mempraktikkan model dialog ini kemungkinan dipengaruhi oleh beberapa faktor, diantaranya karena kurang tepatnya metode pembelajaran yang digunakan oleh guru. Dengan kata lain metode yang digunakan guru untuk mengajar 
berbicara masih belum tepat. Pengajaran bahasa harus dimulai dengan memperdengarkan bunyi-bunyi bahasa dalam bentuk kata atau kalimat kemudian mengucapkannya sebelum pelajaran membaca dan menulis. Maka, metode yang paling cocok adalah metode audio lingual. Metode ini didasarkan atas asumsi bahwa bahasa adalah kebiasaan. Suatu perilaku akan menjadi kebiasaan apabila diulang berkali-kali. Oleh karena itu, pengajaran bahasa harus dilakukan dengan teknik pengulangan atau repetisi. Prinsip dasar metode ini adalah mengajarkan bahasa, bukan mengajarkan tentang kaidah bahasa. Oleh karena itu pelajaran bahasa harus diisi dengan kegiatan berbahasa bukan kegiatan mempelajari kaidah-kaidah bahasa.

\section{Kata kunci: Metode Audio Lingual, Pengajaran Bahasa Arab}

\section{أ. ألمقدمة}

بالحقيقة كل طفل لدياه القدرة على إتقان اللغة، وإن كان في مختلف المستويات ومحركات الأقراص. ومن بين الاختلافات يعني أهداف التعليم التي يتعين تحقيقها، والمهارات الأسـاسية التي لديها، والدافع في الذات والاعتمام والمثابرة. اللغة هي حقيقة أن ينمو ويتطور وفقا لنمو المستخدمين لغة الإنسان . حقيقة اللغة في هذه الحياة متزايد من قوة الوجود

\section{الإنساني كمخلوق الثقافية والدينية.'}

يتكلم عن اللغة، سنعترف بوجود لغة الثانية أو لغة الأجنبية أخرى غير اللغة الأم.

والأهداف الرئيسي من تعلم لغة الأجنبية هو متزايد قدرة الطلاب على استخدام اللغة سواء الشفهية والكتاباة. وتسسمى القدرة على استخدام اللغة في عالم تعليم اللغة المهارات اللغوية. كل مهارة ترتبط ارتباطا وثيقا بعضهيا، لأنه في اكتساب المهارة اللغوية عادة بالعلاقة منظماة. بالمنظمة يتعلم الناس الإستماع والكلام والإستمرار في تعلم التواصل المكتوب (القراءة والكتابة)' . المعلمين في تدربس الأرعح المهارات اللغوية، المهم جدا للمعلمين أن يكون متنوعة من الطرائق.

الطربقة هي الخطة التي يرسمها المعلم ليحقق بها الهدف العمليات التعليمية في أقصر وقت بأقل جهد من جانبـاه ومن جوانب الطلاب. إن الطربقة وسيلة نتبعها لتفهيم الطلاب أي درس من الدروس في أية مادة من المواد. عندما يتقن المعلم طر:قة التعلم، وأفضل

\footnotetext{
${ }^{1}$ Acep Hermawan, Metodologi Pembelajaran Bahasa Arab, (Bandung: PT. Remaja Rosda Karya, 2011), 8.

${ }^{2}$ Abdul Hamid, Uril bahruddin, Bisri Mustofa, Pembelajaran Bahasa Arab: Pendekatan, Metode, Strategi, Materi dan Media, (Malang: UIN Malang Press, 2008), 27.
}

$$
\text { ` محمد عطية الأبراشي، ووح التربية والتعليم، القاهرة :دار أحياء الكتب العربية، } 19 .
$$


إستخدام الطر:قة. عندما يتقن تجري جيدا، وكذلك أفضل لاستخدام الطرائق. في تعليم

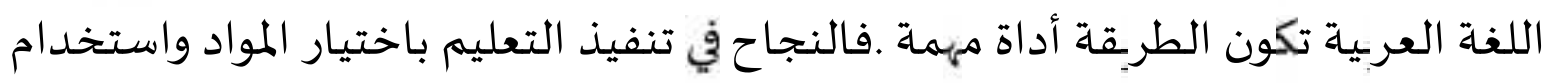

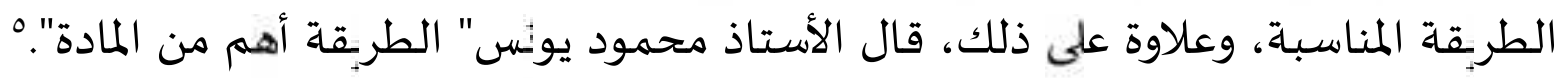

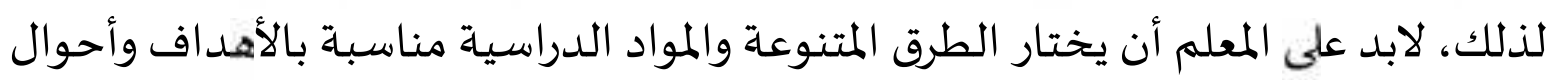
الطلاب.

هناك العديد من الطروق في تعليم اللغة العربية، واحدة منها هي الطربقة السمية

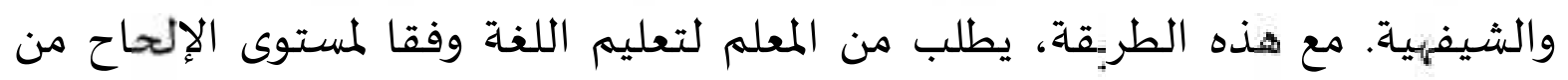

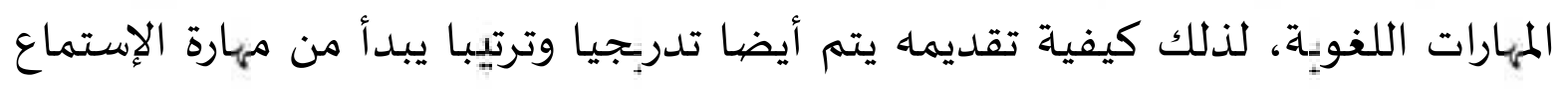

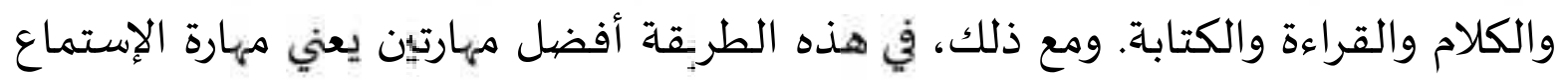
والكلام، ولكن باستخدام هذه الطربقة لابد تعليم مهارتين أخرى يعنى مهارة القراءة ولدهاء والكتابة.

\section{ب. نشأة الطربقة السمعية الشفهية}

بعد أن وضعت الحرب العالمين الثانية أوزارها، بدأت العلاقات الدولية تنمو

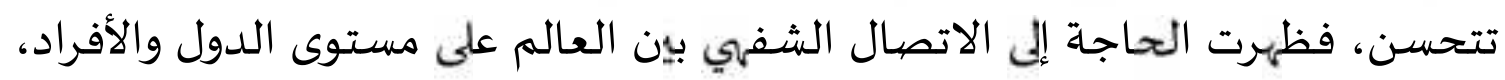

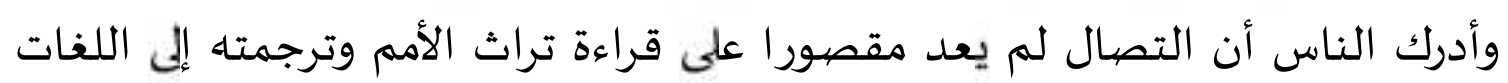
الأخرى. ثم شعرت دول كبرى بالحاجة الملحة إلى تعليم اللغات مواطنيها والمسؤولين فيها،

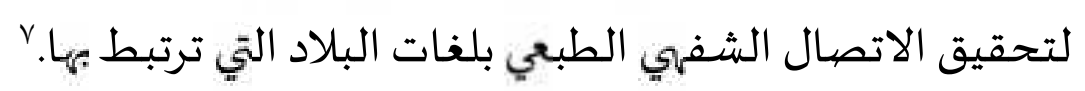

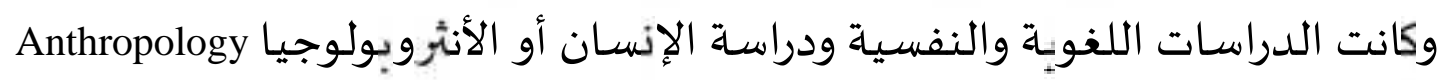

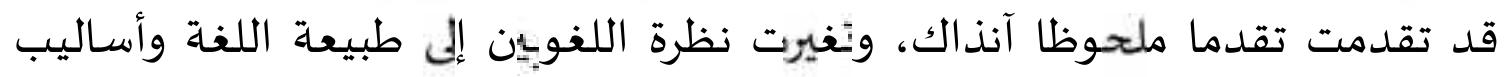
اكتسابها وتعلمها ونعليمها، فظهرت مداخل ومذاهب لقدات لتعليم اللغات الأجنبية، تهتم

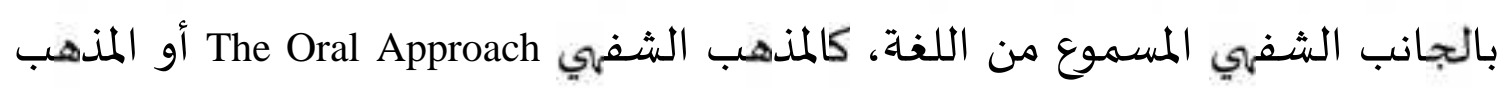

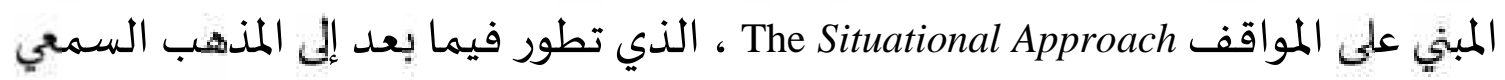

\footnotetext{
${ }^{4}$ Ulin Nuha, Ragam Metodologi dan Media Pembelajaran Bahasa Arab, (Yogyakarta: Diva Press, 2016), 147.

5 Azhar Arsyad, Bahasa Arab dan Metode Pengajarannya: Beberapa pokok Pikiran, (Yogyakarta: Pustaka Pelajar, 2003), 66.

${ }^{6}$ Uril bahruddin, Rekonstruksi Pengembangan Pendidikan Bahasa Arab, (Sidoarjo: Lisan Arabi, 2017), 74-75.

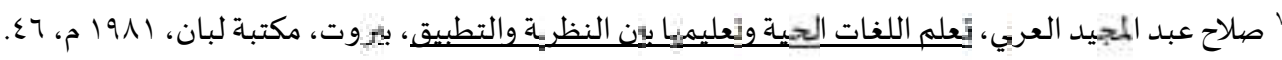


الشفهي، وقد تمخضت عن هذه المداخل طرائق لتدربس اللغات، كان من أبرزها الطربقة السمعية الشفهية. فالطر:قة السمعية الشفهية إذن لم تظهر نتيجة عدد من الأسباب والعوامل السياسية والعملية، التي يمكن إيجازها في النقاط التالية:

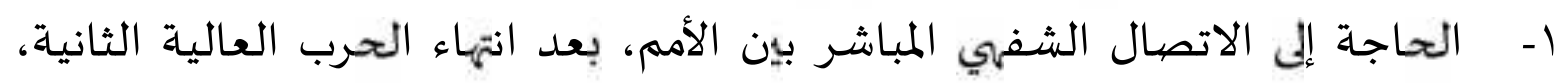

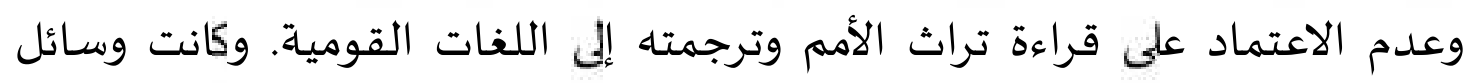

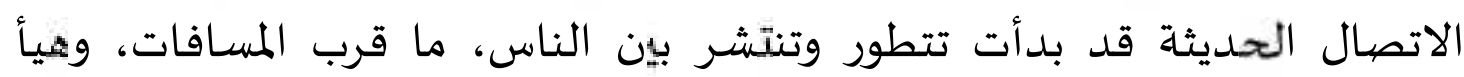
الظروف للاتصال الشفهي المباشر بين الدول والشعوب، فظهرت الحاجة إلى تعلم

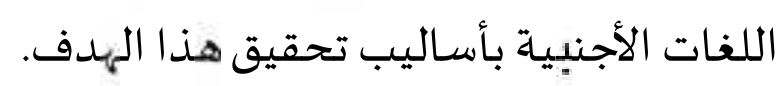

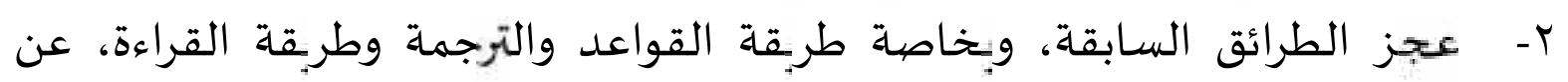

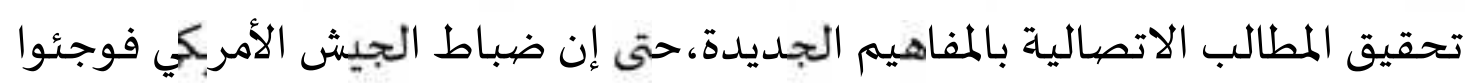

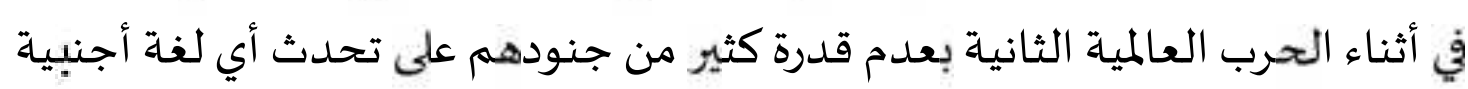
بطلاقة كافية.9

r- التطور في الداراسات اللغوية النفسية في منتصف القرن العشربن، الذي انتهى

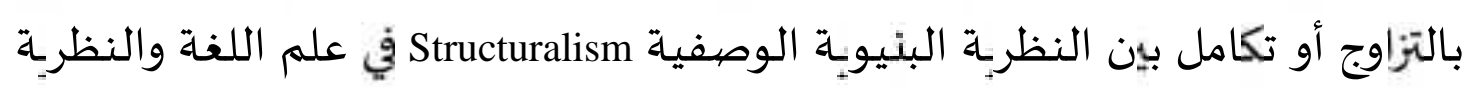
الحسية السلوكية Behaviorism في علم النفس، وتبلور -نتيجة لذلك- اتجاه الذي ينظر إلى اللغة نظرة شفهية شكلية.

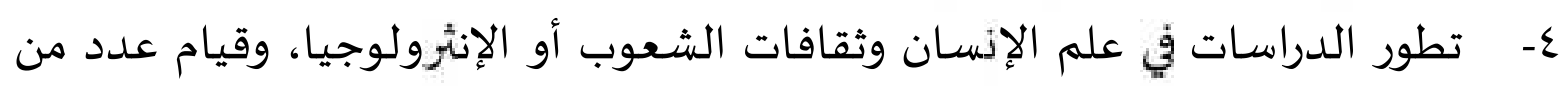

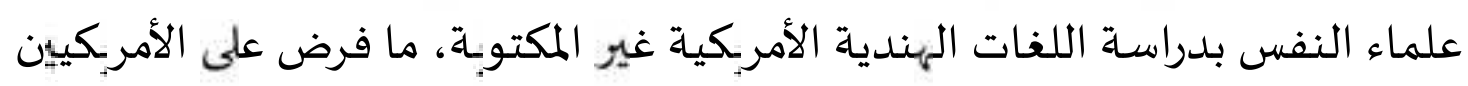

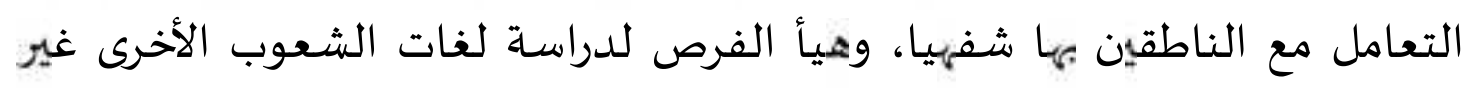
المكتوبة في آسيا وأفربقيا وأمربكا الجنوبية.

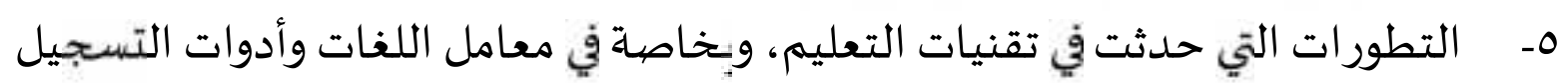

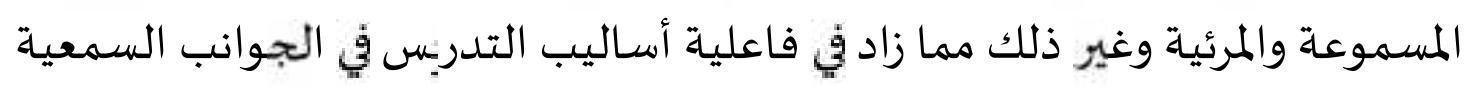
الشفهية.

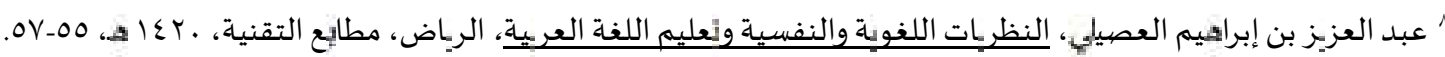

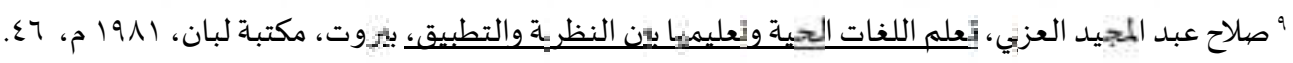

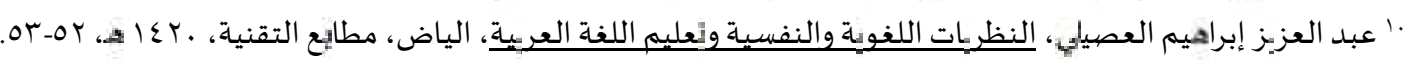


7- نتيجة لهذه الأسباب والعوامل، برز الاعتمام بالجوانب السمعية الشفهية من اللغة، فظهر المدخل السمعي الشفهي The Aural-oral Approach في تعليم اللغات، الذي الذيان

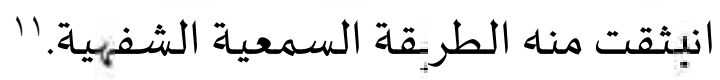
ونعد الطربقة السمعية الشفهية طربقة أمر:كية في نظر كثير من الباحثين في ميدان تعليم اللغات الأجنبية. يستدلون على ذلك بما حدث للجيش الأمركي إبان

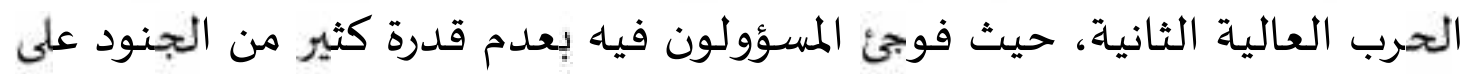

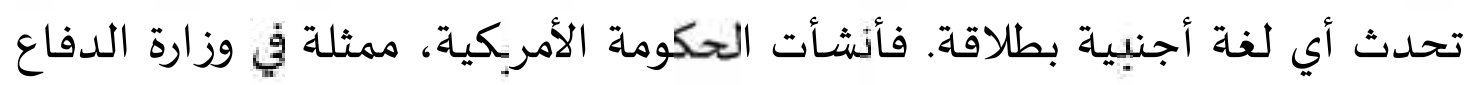

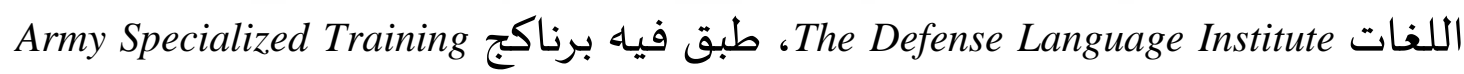
بهدف مساعدة الضبط والجنود الأمر:كيين على اكتساب لغات برئ Program (ASTP)

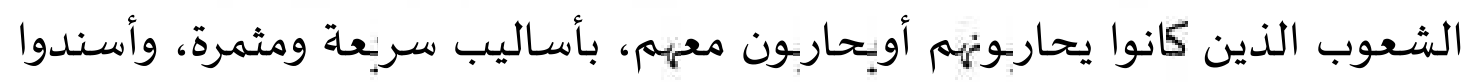

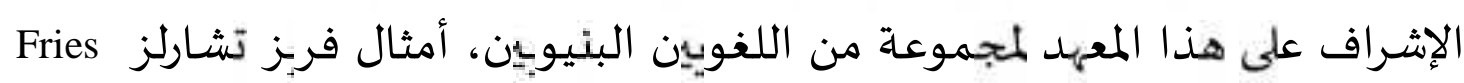

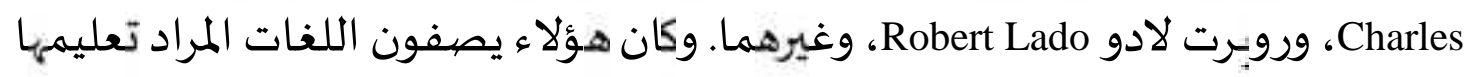

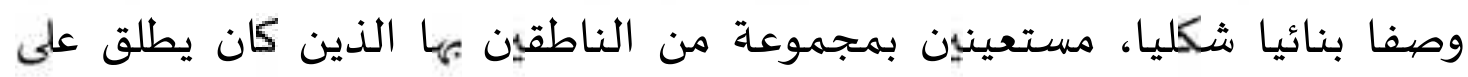

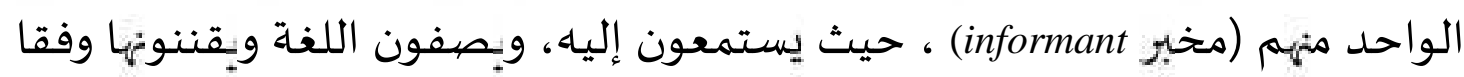

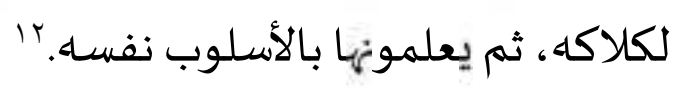

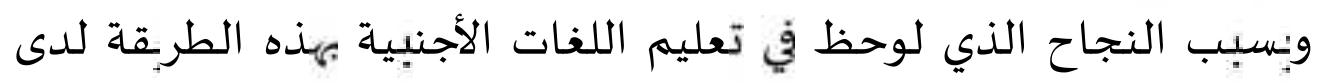

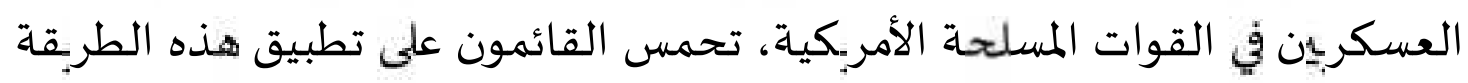

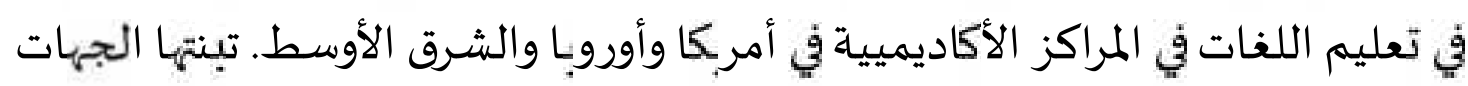

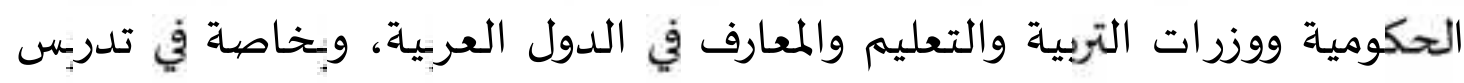

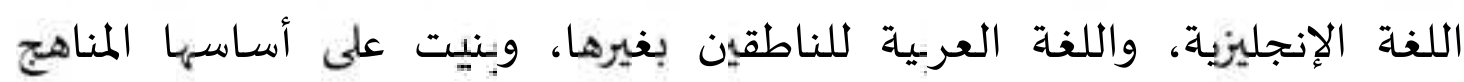

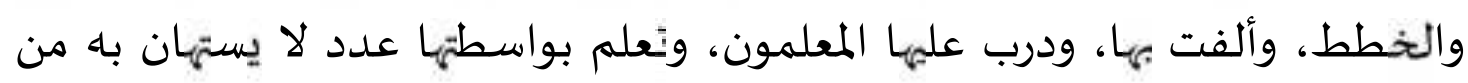
الدراسين فترة زمنية طويلة.

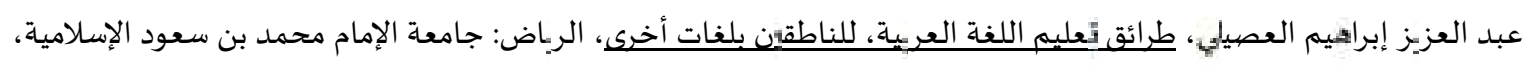

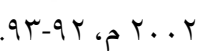

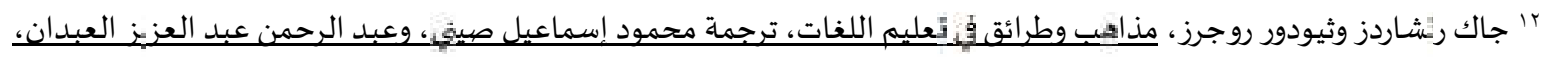

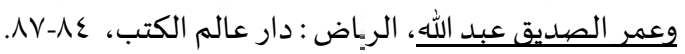


والواقع أن هذه الطربقة، وإن شاع استعمالها في أمربكا، كان لها جذور بربطانية

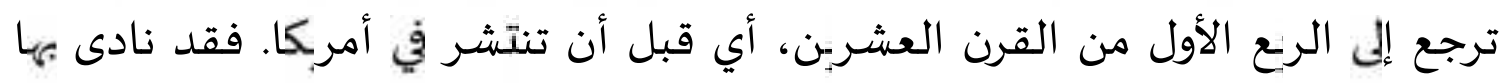

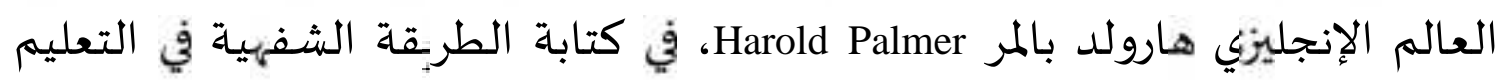
اللغات The Oral Method in Language Teraching، التي صدرت الطبعة الأولى منه علم ابT 9 م. فهذه الطربقة إذن أوروبية المنشأ، أمربكية الاستعمال والانتشار.

\section{ج. النظربة التي تنتمي إلهيا الطربقة السمعية الشفهية}

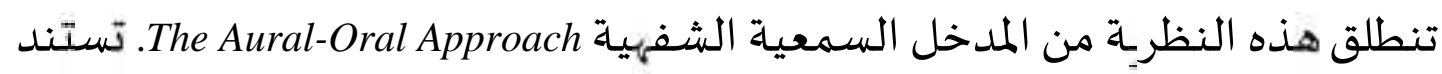
الطربقة السمعية الشفهية إلى بعض ما انتهت إليه دراسات علم النفس وعلم اللغة في خمسينيات وستينيات هذا القرن وفيما يلي إجمال لهذه النتائج: 1. من حيث علم النفس: تعليم هذه الطربقة بالنظرية السلوكية Behaviorism والتي

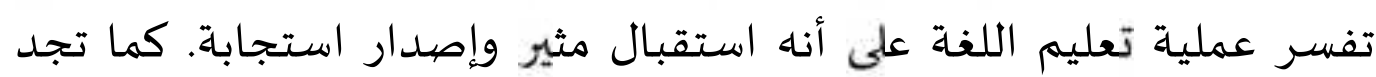
قوانين الاقتران الشرطى Operant Conditioning ومفاهيم التعزبز تطبيقاتها في هذه الطربقة. r. ومن حيث علوم اللغة: فقد سجل لنا مولتون خمسة شعارات تمثل نتائج هامة من نتائج البحث اللغوي. هذه الشعارات الخمسة هي التي سماها مولتون شعارات العصSlogans Of The Day وتلخصهيا وليجا ربفرز فيما يلي: اللغة كلام وليست كتابة، تعلم اللغة مجموعة من عادات وتكتسب هذه العادات بمثل ما تكتسب العادات الاجتماعياة،علم اللغة وليس عن اللغة، إن اللغة هي ما يمارسـا

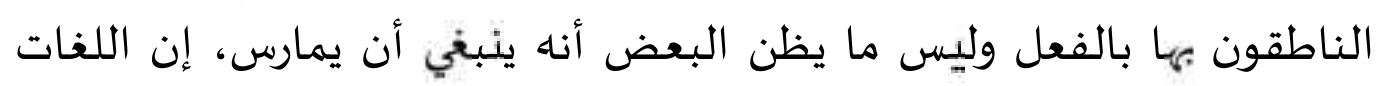

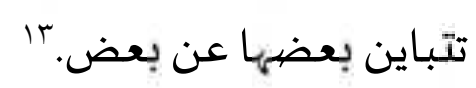

د. أهداف الطربقة السمعية الشفهية وملامحها أما أهداف الطريقة السمعية الشفهية وملامحها هي ينبغي أن يبدأ في تعليم الدارس وملامجيا اللغة الهدف بمهارات الاستماع، تلهيا مهارات الكلام، ثم مهارات القراءة، فمهارات

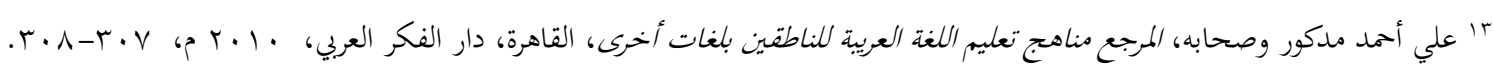


الكتابة، على أن يكون الاتصال الشفهي باللغة هو الهيدف الأسمى من العملية التعليمياة،

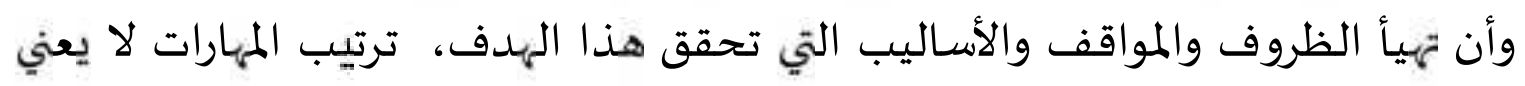

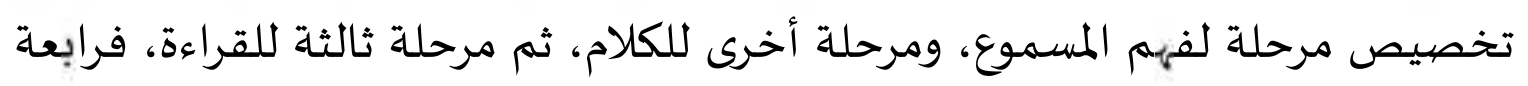

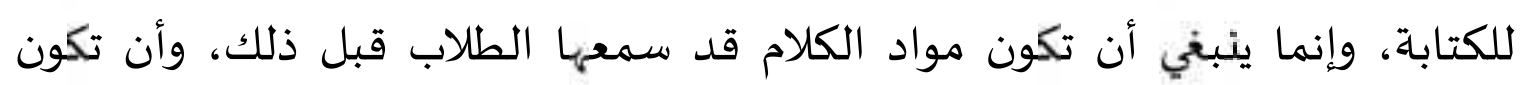

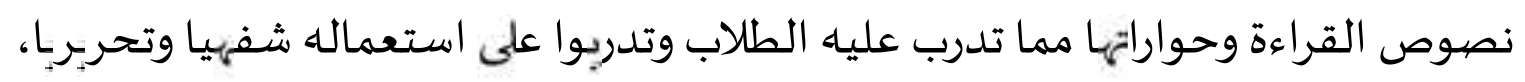
مراحل التعلم تبدأ بالحفظ يليه التقليد فالقياس، ثم يأتي التحليل في مرحلة متأخرة.

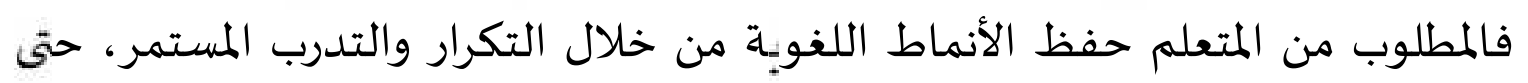

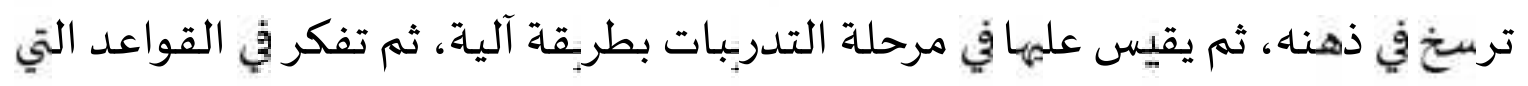
تحكم هذه الأنماط، تهتم هذه الطربقة بقواعد اللغة، وتبني عليها المواد اللغوية المقررة،

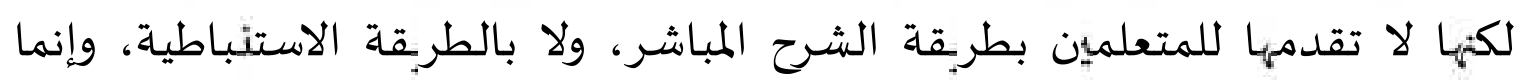
تقدمها من خلال نصيوص وحوارات، بأساليب غير مباشرة، في كل شكل أنماط لغوية لفرية

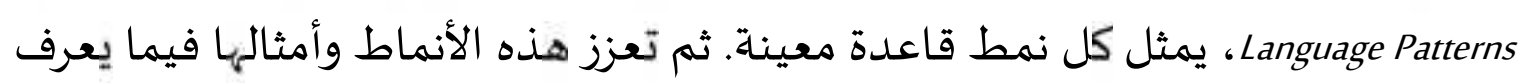

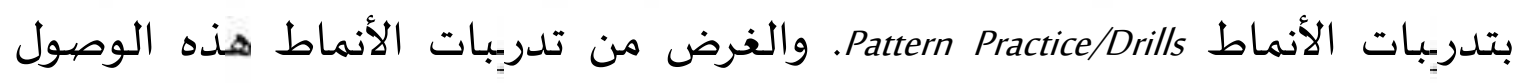

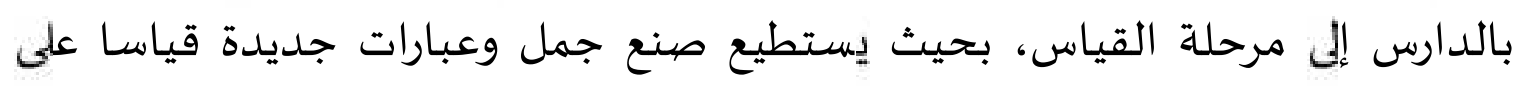

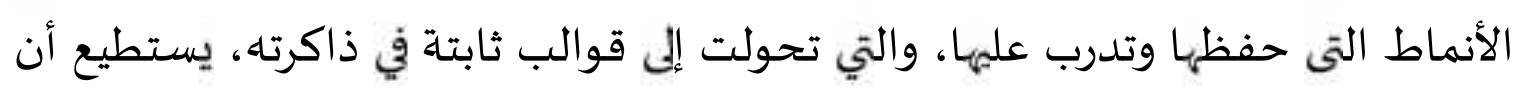

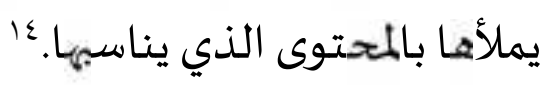

وظائف كل من المعلم والمتعلم والمواد التعليمية في الطربقة السمعية الشفهيية ينقسم إلى ثلاثة أقسام فهي وظائف المعلم والمتعلم و المواد التعليمية.

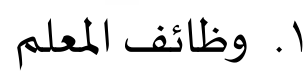

وظائف المعلم محدودة جدا، ومحكومة بالمواد والكتب المقرر التي

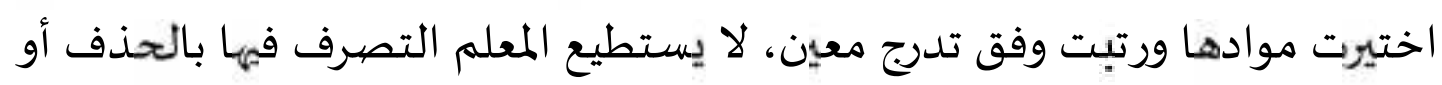

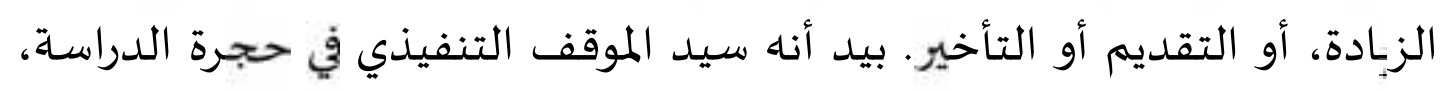

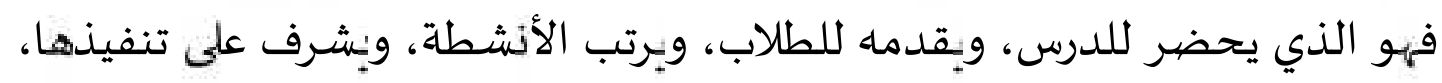

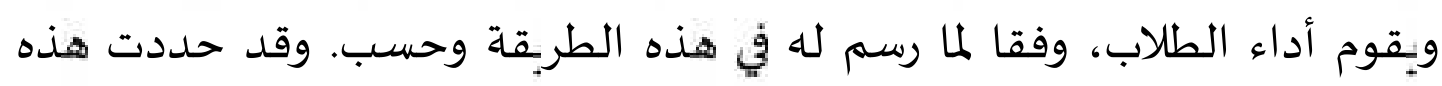

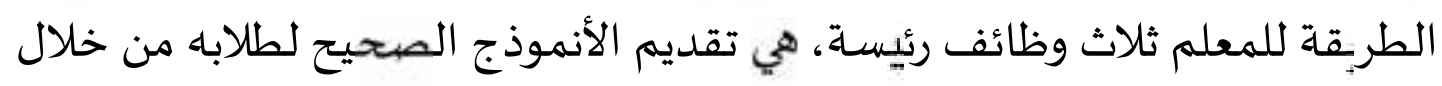


النطق السليم والاستعمال الصحيح للغة، قيادة الطلاب وتنظيم أنشطتهم في حجرة الدراسة و مراقبة نطق الطلاب وتصحيح أخطائهم وتقويم أدائهم، أولا بأول. 10 r. r. بائف المتعلم

من الواضح أن المتعلم أضعف عنصر في العملية وفقا لهذه الطربقة، إذ لا حولا له

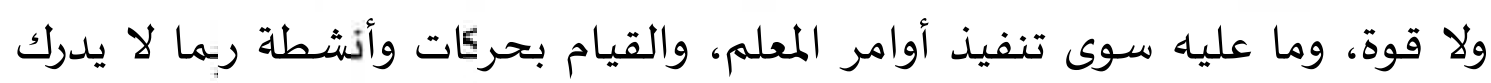

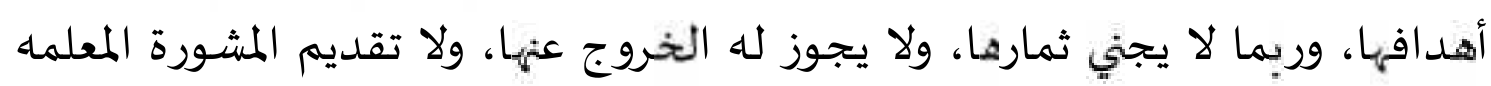

$$
\text { r. المغلوب على أمره. } 17
$$

تعتمد الطربقة السمعية الشفهية اعتمادا كليا على المواد التعليمية المقرر في المنهج، سواء أكانت مسموعة أم مكتوبة. وقد أشرنا إلى أن هذه المواد يتم اختيارها

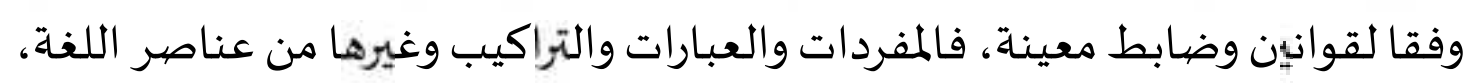

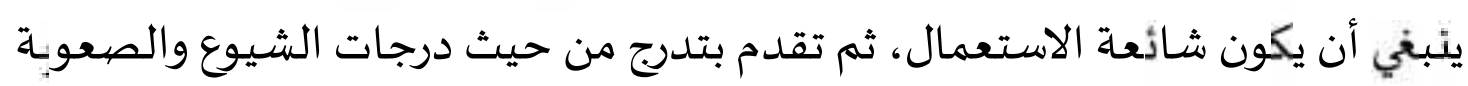

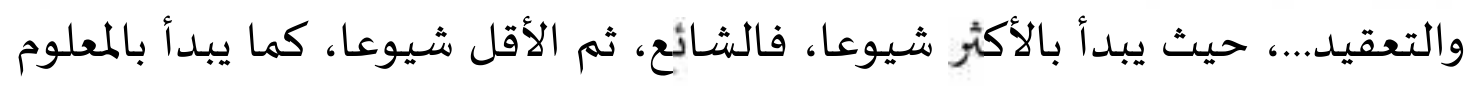
قبل المجههول، وبالسهل قبل الصعب، وبالبسيط قبل المعقد وهكذا. وتبني مواد القراءة مرتبة وفق ترتيب الأنماط اللغوية التي تقدم من خلالها قواعد اللغة، ويتم التدرب

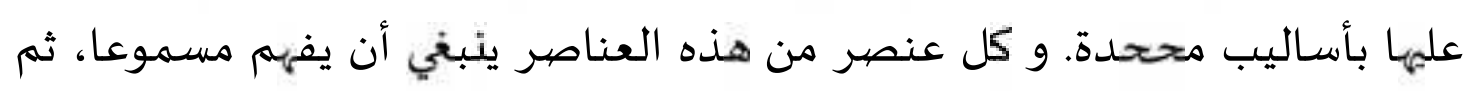

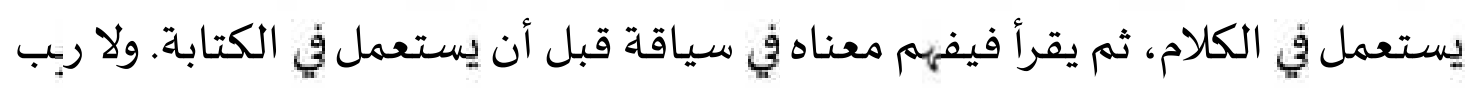

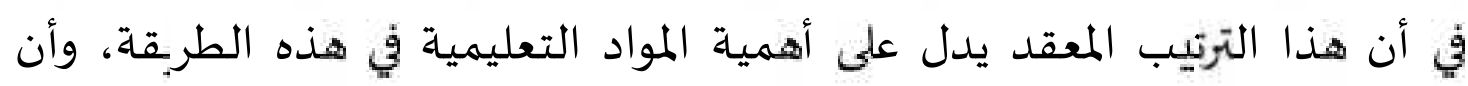

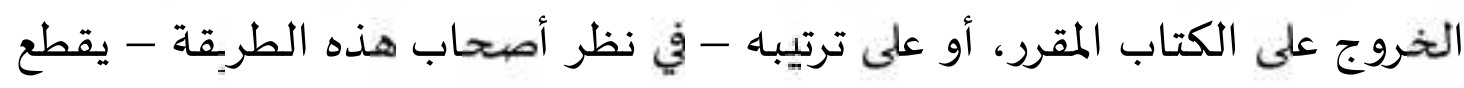

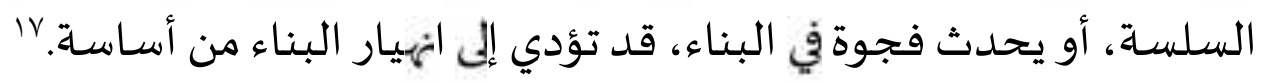

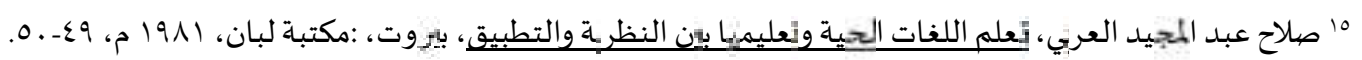

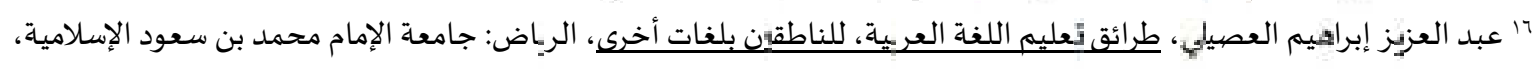

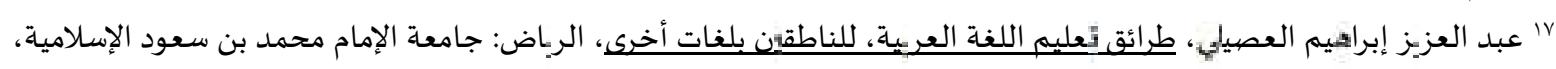




\section{ذذ مزايا الطربقة السمعية والشفهية وعيوبها}

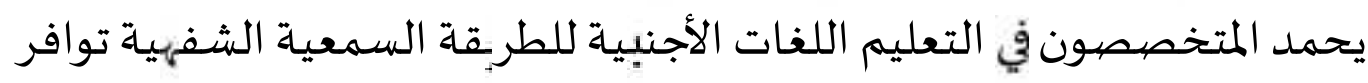

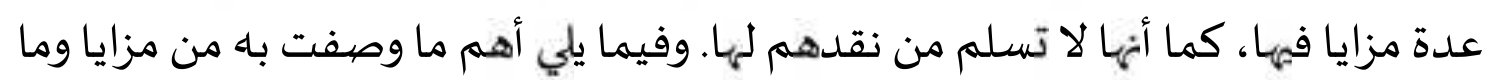

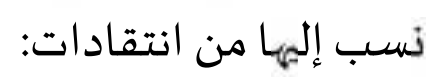
أ) مزايا الطربقةالسمعية والشفهيية النادية أما مزايا الطربقة السمعية والشفهيية فهي: ا. الا هتمام بالجانب الشفهي من اللغة، انطلاقا من نظرة هذه الطربقة لطبيعة اللغة

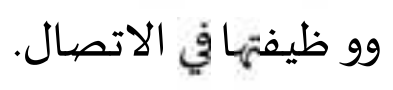

r. الا هتمام بثقافة اللغة الهيدف بمفومها الشامل ، والحرص على تقدم نماذج الإن منها في الموقف الحياة العادية، من خلال الصور والأفلام والاشرطة السمعية.

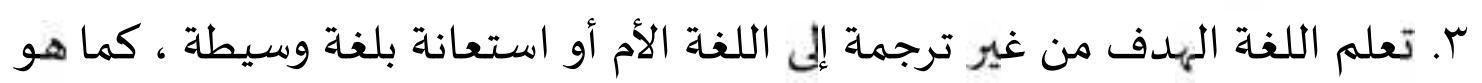

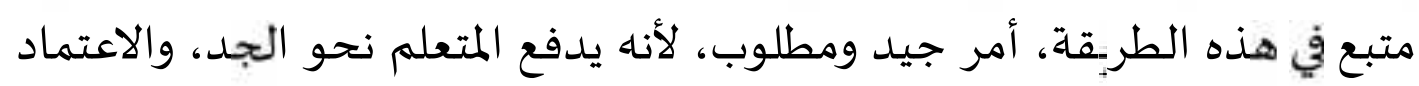

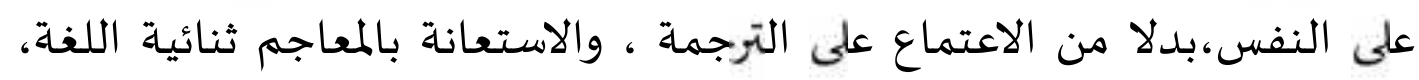

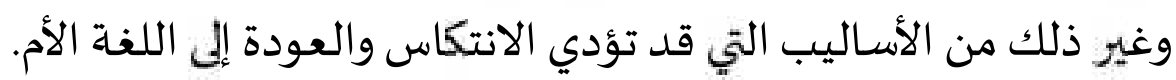

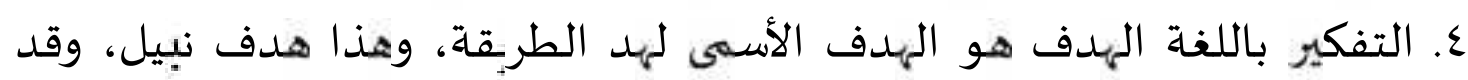
ضعت عدة وسائل لتحقيقه، كالحديث الشفهي، والابتعاد عن الترجماة، والاستعانة التهانة بتقنيات التعليم، كاالصور والأفلام واشرط التسجيل.

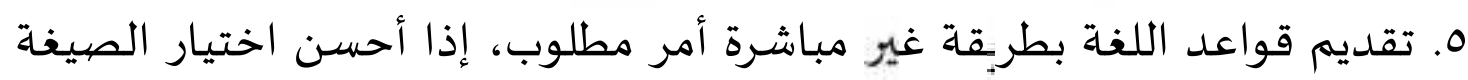
الصرفية والأواب والوظائف النحوية، ولم يبالغ في التدربب عليه الهيها بأساليب الية.

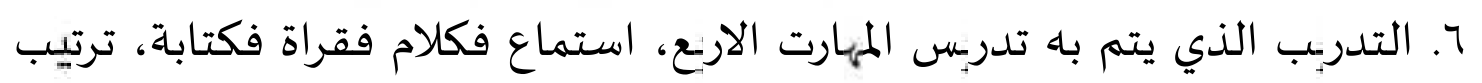

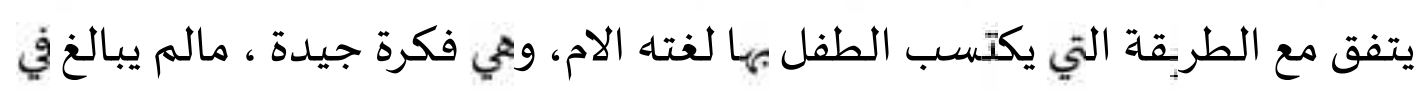
الاعتماد عليها.

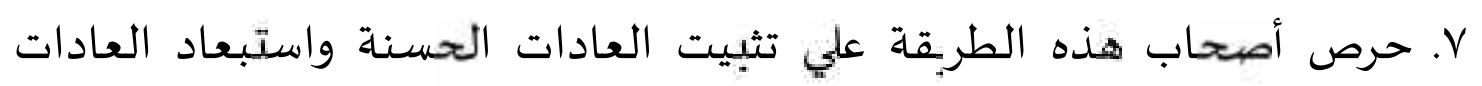

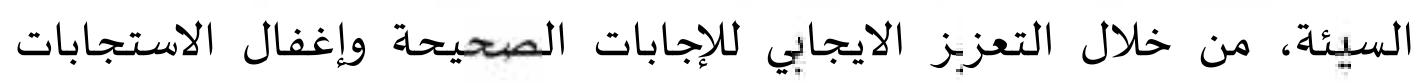

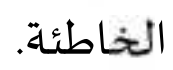


ه. التدرج في التقديم المواد والعناصر اللغوية، يعد خطوة جيدة، مالم يتحول إلى تكلف وتصنع.

9. التأكيد على أهمية التدرببات في استعاب اللغة، ونسبيت كثير من المهارات، فضلال

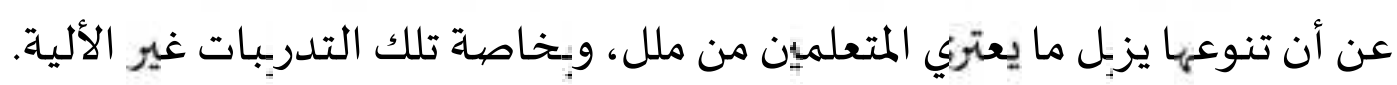
. . بعض أنشطة هذه الطربقة تعود المتعلم على الاستماع الجيدوسلامة النطق، وقد تشجعاء على الانطلاق في ممارسة اللغة.

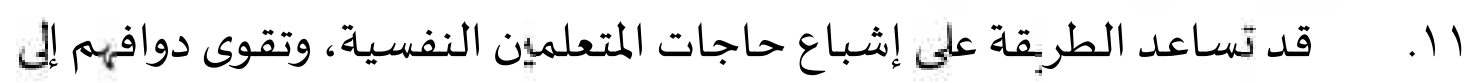

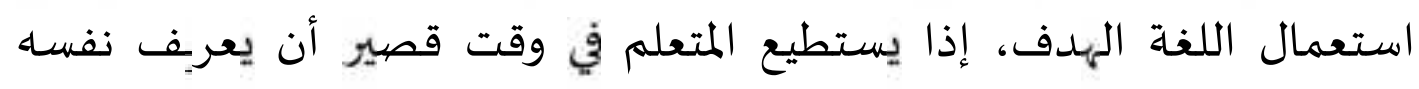

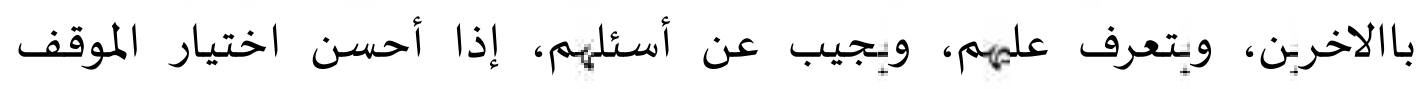

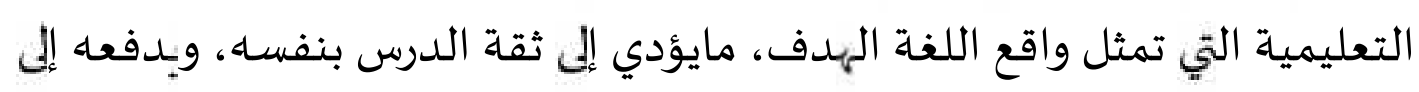

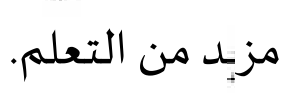

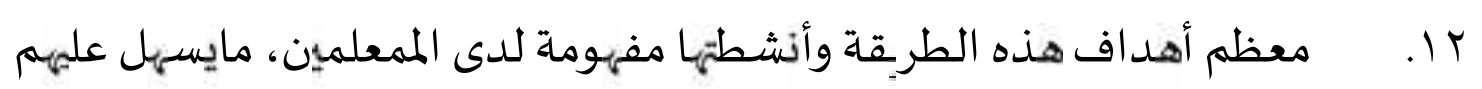

$$
\begin{aligned}
& \text { تنفيذ خطواتها وأنشطها، وتقوبم أداء الطلاب." } \\
& \text { r }
\end{aligned}
$$

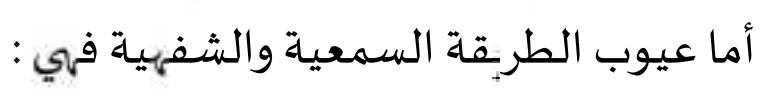

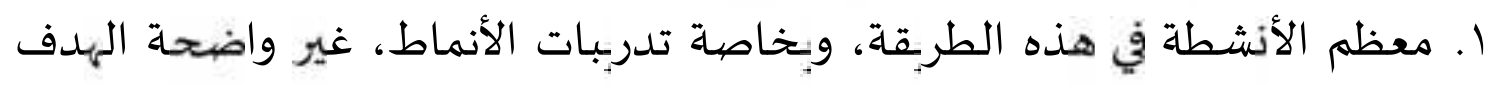

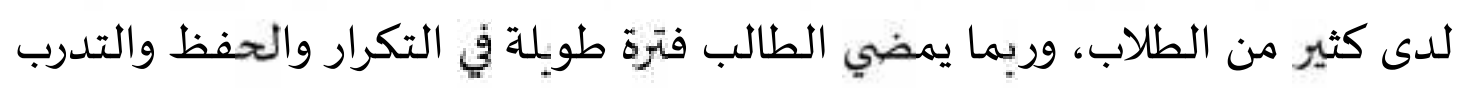

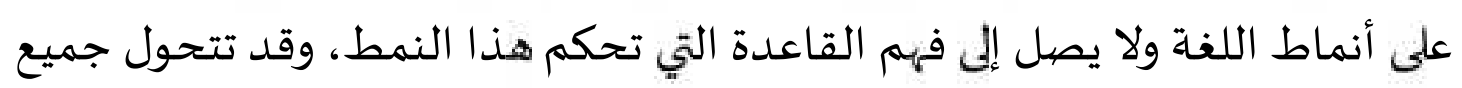

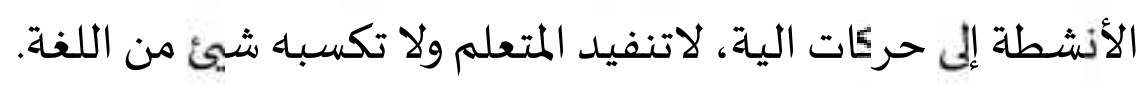

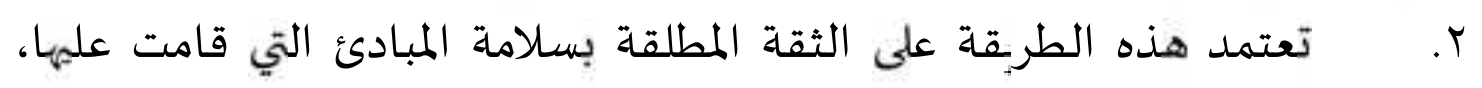

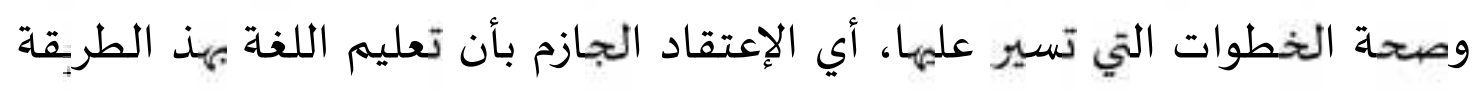

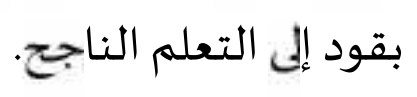

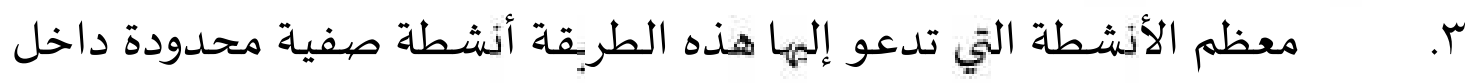

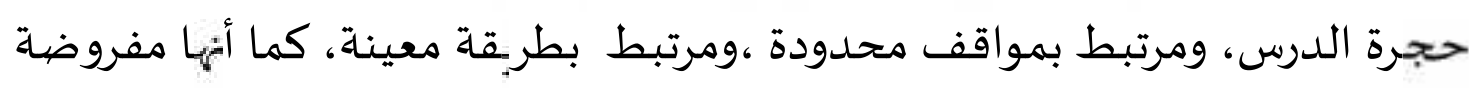

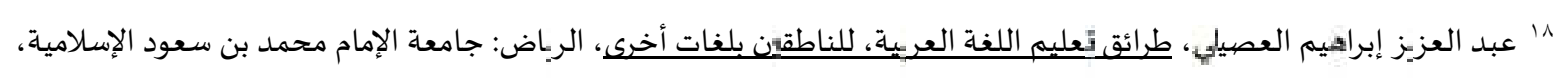


على المتعلمين، مايحول دون الإستفادة منها في استعمال اللغة في الحياة اليومية العامة بطر:قة عفوية. ع. بنيت النصيوص في هذه الطربقة على موقف اللغة، التي هي عبارة عن مواقف اتصالية تحدث في مجتمع اللغة الهدف، كالحجز للسفر، والبيع والشراء،

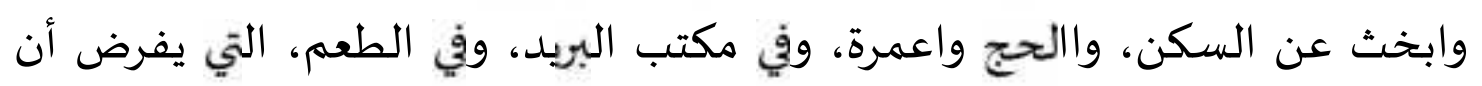

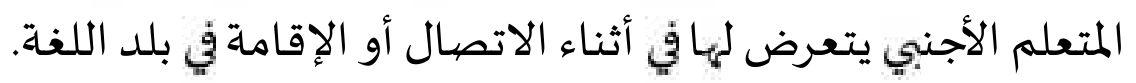

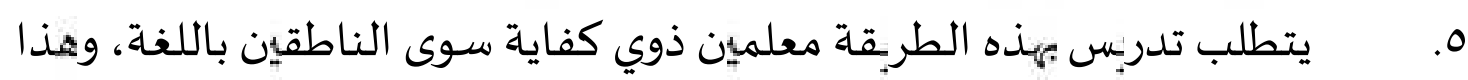

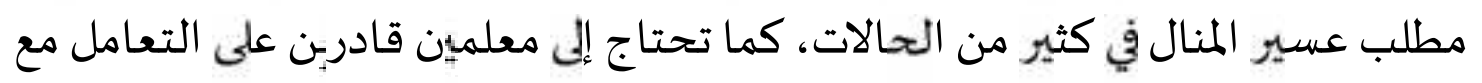

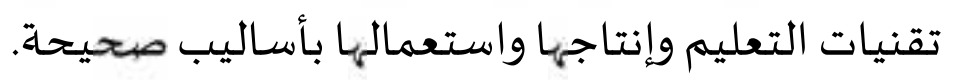

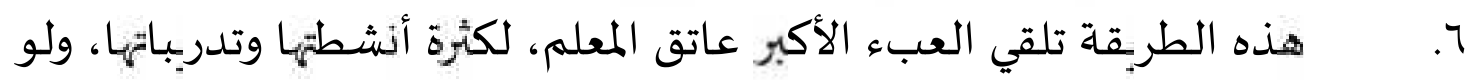

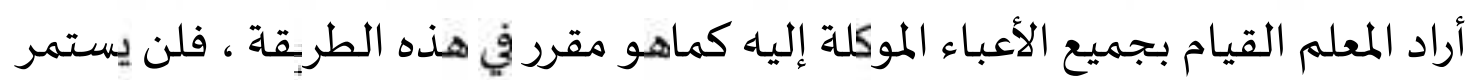
طويلا في مهنته، وقد يسبب عناء ومللا لطلابة.

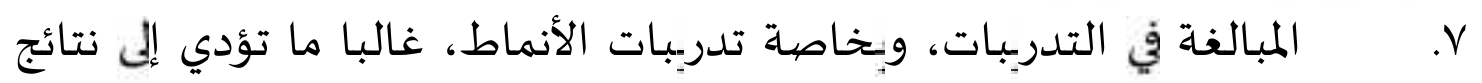

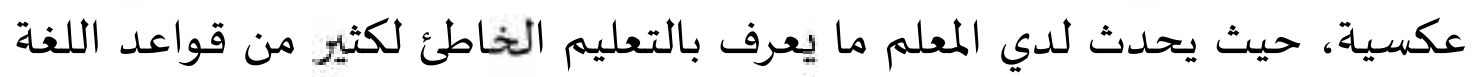

\section{ر. استخدام الطربقة السمعية والشفهية في تعليم اللغة العربية} تختلف إجراءات التدربس في هذه الطربقة حسب مستوى الطلاب في اللغة الهيدف،

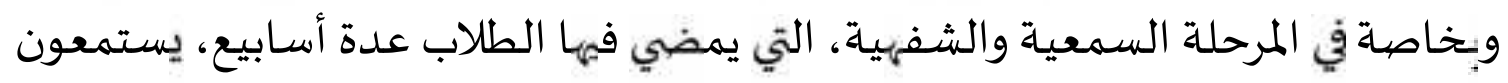

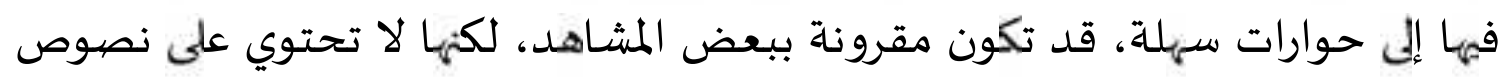

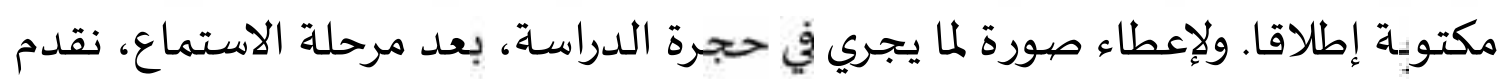

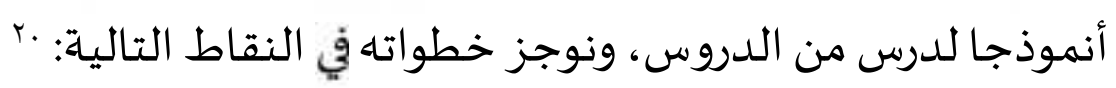

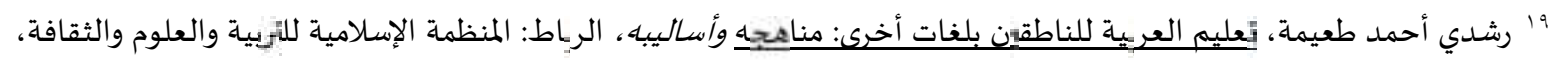
.1 \% . A $|\varepsilon|$.

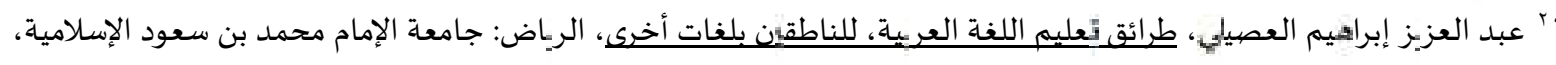


ا. يدخل المعلم إلى الصف، ويسلم على الطلاب، حاملا معاه الكتاب المقرر، تصور معن النص ومشاهدة، وتسـاعد الطلاب على الفههم. r. بقرأ النص الأساس جملة جملة

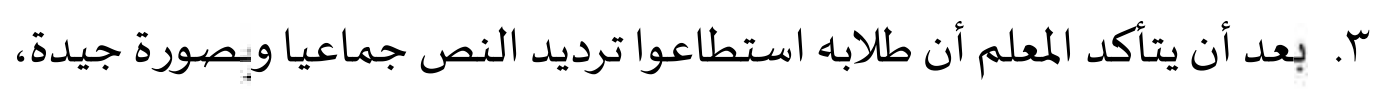

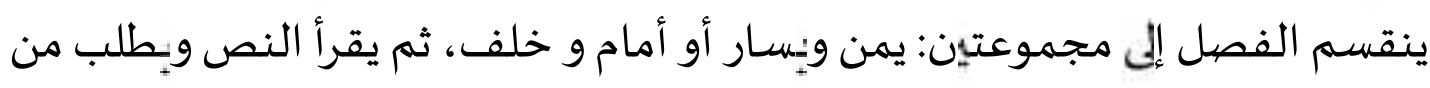

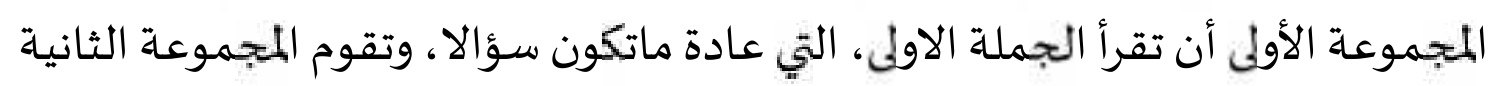
بقراءة الجملة الثانية ، التي هي جواب الجملة اللأولى.

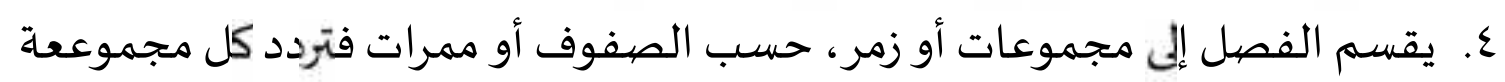
عبارة أو جملة أوجزءا من الحوار، وتكمل المجموعاة التي بعدها الجزء التهاء الذي يليها.

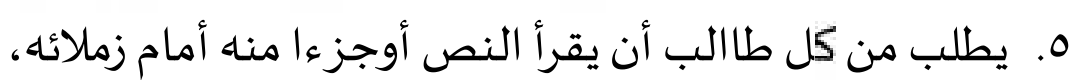
بصوت واضح. 7 7. ينتقل المعلم بعد ذلك إلى تدرببات الأنماط التي تعد مرحلة مهماة، بل هي قوام هذه الطربقة. V. ينتقل المعلم إلى نمط اخر من تدربب، يسمى لعب الأدوار (role play).

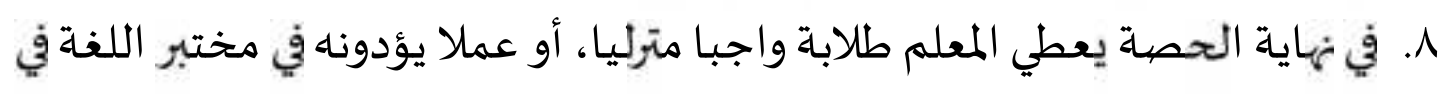

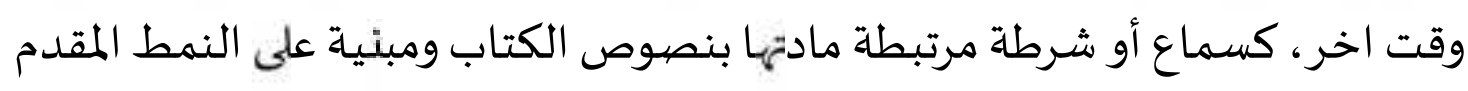
لهم في الدرس.

\section{ز الاختتام}

نشأة الطربقة السمعية الشفهية وضعت الحرب العالمين الثانية في أمربكيا بهدف مساعدة الضبط والجنود الأمر:كيين على اكتساب لغات الشعوب الذين كانوا يحاربونهم

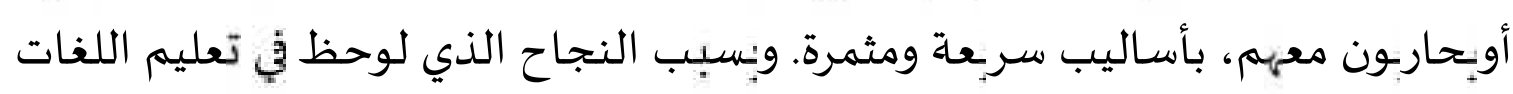
الأجنبية بهذه الطربقة لدى العسكربين في القوات المسلحة الأمربكية، تبنتها الجهات

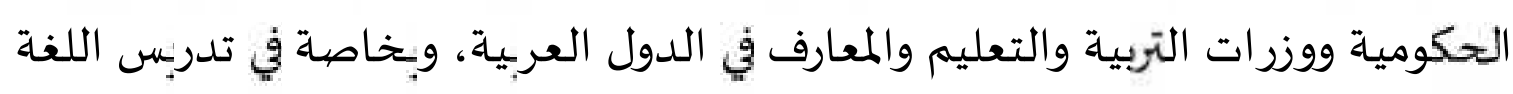
الإنجليزية، واللغة العربية للناطقين بغيرها. 
النظربة التي تنتمي إلهها الطربقة السمعية الشفهية هي النظربة في علم النفس يعني والنظربة السلوكية في علم اللغة هناك الشعارات الخمسة هي التي سماها مولتون شعارات العصرSlogans Of The Day. في هذه الطربقة وظائف كل من المعلم والمتعلم

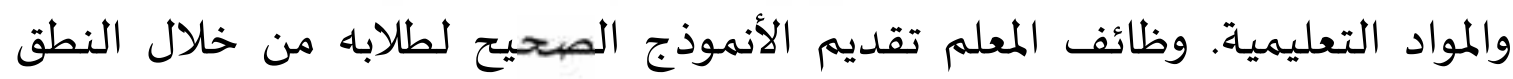

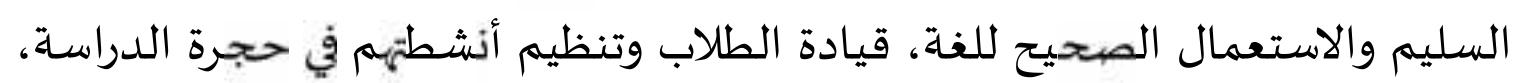

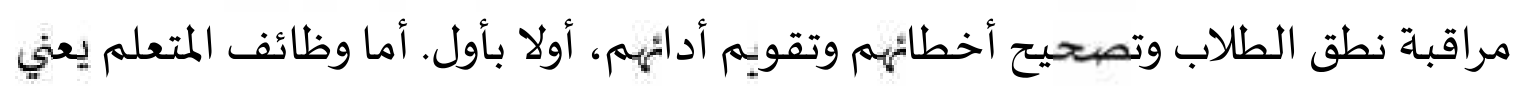

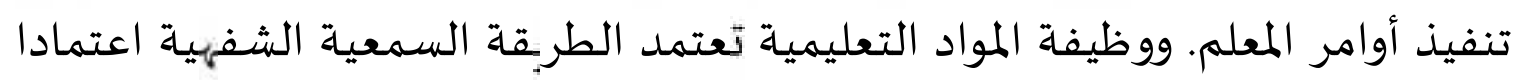

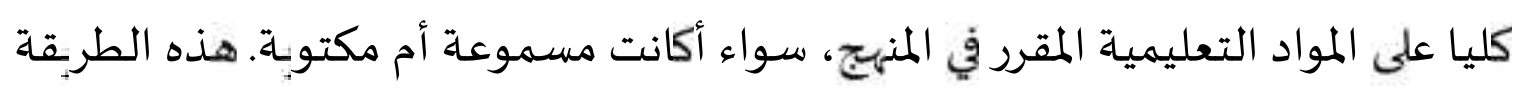

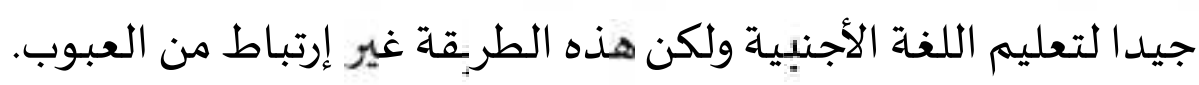

\section{المراجع}

صلاح عبد المجيد العربي. نعلم اللغات / تحية وعليمها بين النظربة والتطبيق. بيروت. مكتبة

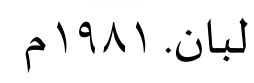

عبد العزبز بن إبراهيم العصيلي. النظريات اللغوبة والنفسية ومعليم اللغة العربية. الرباض.

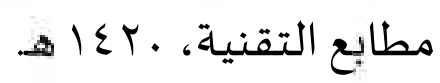
عبد العزبز إبراهيم العصيلي. طرائق نعليم اللغة العربية، للناطقبن بلغات أخرى. الرباض.

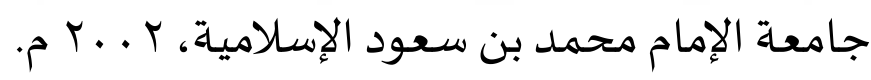

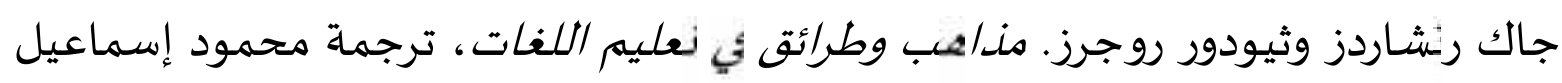

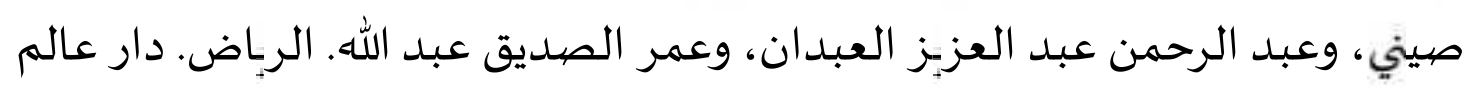
الكتب. علي أحمد مدكور وصحابه. المرجع مناهج نعليم اللغة العريبة للناطقبن بلغات أخرى.

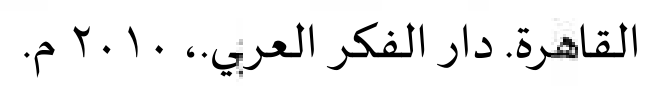

رشدي أحمد طعيمة.. نعليم العربية للناطقبن بلغات أخرى: مناهجها وأساليبه. الرباط.

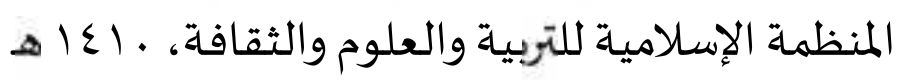


محمد عطية الأبراشي. روح النبرية والتعليهم. القاهرة. دار أحياء الكتب العربية.

\section{المراجع الأجنبية}

Azhar Arsyad, Bahasa Arab dan Metode Pengajarannya: Beberapa pokok Pikiran. Yogyakarta: Pustaka Pelajar, 2003.

Bahruddin Uril, Rekonstruksi Pengembangan Pendidikan Bahasa Arab. Sidoarjo: Lisan Arabi, 2017.

Abdul Hamid dkk, Pembelajaran Bahasa Arab: Pendekatan, Metode, Strategi, Materi dan Media. Malang: UIN Malang Press, 2008.

Acep Hermawan, Metodologi Pembelajaran Bahasa Arab, Bandung: PT. Remaja Rosda Karya, 2011.

Ulin Nuha, Ragam Metodologi dan Media Pembelajaran Bahasa Arab. Yogyakarta: Diva Press, 2016. 